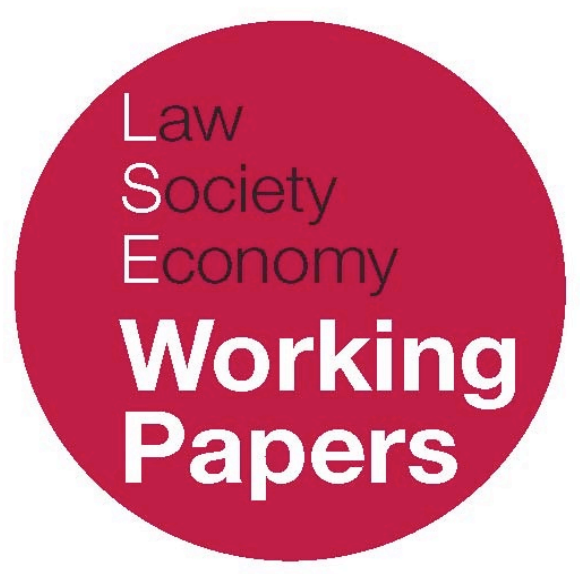

\title{
Immanence and Irreconcilability: \\ On the Character of Public Law as Political \\ Jurisprudence
}

Jacco Bomhoff

Forthcoming in: M. Wilkinson \& M. Dowdle (eds.),

Questioning the Foundations of Public Law

(Hart Publishing, 2018)

LSE Law, Society and Economy Working Papers 19/2017

London School of Economics and Political Science

Law Department 
Immanence and Irreconcilability:

On the Character of Public Law as Political Jurisprudence

\author{
Jacco Bomhoff*
}

\begin{abstract}
In Foundations of Public Law, Martin Loughlin constructs an intricate conceptual triangle made up out of religion, law, and politics, in order to offer an account of the character of public law as a secular, political, jurisprudence. In this essay, I argue that this account takes neither religion nor law seriously - and this in revealingly similar ways.

Loughlin's book presents public law as an irreducibly paradoxical discourse, devoted to sustaining 'the irreconcilable' within society. Relative to this discourse, religion - understood by Loughlin as absolutist dogma - appears in the book only as a threat, whereas law - seen as a mere tool - becomes a necessary and innocent means for its support. I offer a critique of both these lines of argument, as not sufficiently attentive to religion and law as fields with their own histories, internal dynamics, and forms of efficacy. Religion, when seen in terms of practice, discipline, and ritual, in fact has much in common with - and considerable resources to offer to - Loughlin's own vision of public law. And attention to the legalism so deeply embedded in juristic discourse reveals law as posing precisely the absolutist threat that Loughlin fears (but only associates with religion and 'the social').

Bringing these two lines of argument together, I argue that Loughlin's own ambition for public law as a prudential discourse of contained irreconcilability, is better served, not by striving for radical - and impossible - immanence, but by acknowledging that discourse's dual character as a phenomenon both immanent and transcendent. I also suggest that ritual practice may have an important role to play in maintaining this dual, and paradoxical, character.
\end{abstract}

\footnotetext{
* London School of Economics and Political Science, Department of Law. Thanks to Emmanuel Voyiakis and Mike Wilkinson for comments on an earlier draft.

This paper can be downloaded without charge from LSE Law, Society and Economy Working Papers at: www.lse.ac.uk/collections/law/wps/wps.htm and the Social Sciences Research Network electronic library at: https://ssrn.com/abstract $=3083954$

(C) Jacco Bomhoff. Users may download and/or print one copy to facilitate their private study or for noncommercial research. Users may not engage in further distribution of this material or use it for any profitmaking activities or any other form of commercial gain.
} 


\section{INTRODUCTION}

Public law, Martin Loughlin has long argued, is fundamental law. It is the law that institutes the sovereign. And in its modern liberal form, it is the law that sustains 'the autonomous world of the public sphere'.1 In 'Foundations of Public Law' Loughlin presents an intricate genealogical and conceptual account in which this modern public law emerges to answer questions of political theology by way of a 'political jurisprudence'. My argument in this essay is that this account does not take its own crucial strands of 'religion' and 'law' sufficiently seriously, in revealingly similar ways. The result, I claim, is a conception of public law that is radically immanent in a way that is unrealistic and that hurts rather than supports Loughlin's own ambition for political jurisprudence as guarantor of 'the irreconcilable' within society.

Three claims as to the character of modern public law, developed throughout the book, are central to this argument. First, Loughlin's public law is a resolutely secular phenomenon. The book depicts the birth of an autonomous domain of the political as the outcome of a grand process of secularisation. In this, Loughlin broadly follows the radical account of a transition from 'heteronomy' to 'autonomy' in Marcel Gauchet's 'The Disenchantment of the World. ${ }^{2}$ In this story, the law sustaining political autonomy can evidently no longer be the religious fundamental law familiar to medieval jurists. ${ }^{3}$ Religion in modernity, Loughlin claims, merely lives on as culture, and no longer as a basic structuring force of collective organization'. ${ }^{4}$ It is important to note even at this early stage that Loughlin adds a revealing coda to his secularisation story in his closing pages. There, he identifies a more recent threat to modern public law in terms of a 'return of the religious'. This return, which is not dated with any precision, takes the form of the rise of 'the social', and is manifested in 'overarching claims of the right and the true', voiced, apparently, with growing fervour. ${ }^{5}$

Second, public law is law. It is a form of 'juristic' discourse. This term is not defined in the book, but appears to refer to a familiar catalogue of what we might call legalistic characteristics and values. However, it is also clear that if public law is to remain fundamental in any meaningful sense, it cannot merely encompass the bare 'lex' of posited law. And so instead, Loughlin argues, modern public law takes a distinctive politico-juridical form: that of 'a prudential discourse of political right'. This is public law as political jurisprudence: as 'droit politique' (in Rousseau's term), or as 'the jus of lex' (in Oakeshott's).

${ }^{1}$ M. Loughlin, Foundations of Public Law (Oxford, Oxford University Press, 2010) hereafter FPL, 10, 232.

${ }^{2}$ M. Gauchet, The Disenchantment of the World (O. Burge, trans.) (Princeton, Princeton University Press, 1997).

${ }^{3}$ Cf. FPL, 158 (seeing this as 'axiomatic')

${ }^{4}$ FPL, 8.

${ }^{5}$ FPL, 465 
And third, most importantly, public law is 'unresolvable confrontation' - in its form, function, and aspiration. ${ }^{6}$ The book's central concern is to recover and maintain public law as a form of discourse through which a range of enduring central dilemmas over 'matters of common existence' can be expressed and negotiated, but through which also, crucially, their reconciliation or elimination can be forever deferred. ${ }^{7}$ Loughlin sees these dilemmas as all related to a supposedly universal 'disjuncture between freedom and belonging'. ${ }^{8}$ But more important - and more easily defended - than the precise substance of any specific binary opposition identified, I would argue, is the overall character of his undertaking, as committed to recognising and safeguarding public law's irreducibly paradoxical logic and its essential openness and open-endedness. ${ }^{9}$ Public law thus contains conflict, in the double sense of the verb 'to contain'. ${ }^{10}$ Borrowing an expression from Hent de Vries, it is what allows us to 'dwell in contradiction', together. ${ }^{11}$

In this essay, I ask three broad questions with regard to these dimensions to the character of public law and their relationship to each other. First, if political jurisprudence is indeed, as Loughlin puts it, a 'kind of secularized natural law', then how exactly is it secular? ${ }^{12}$ Second, if public law is to be a 'juristic discourse' sustained by 'lawyers and legal modes of thinking', but if it is, at the same time, threatened by positive law and excesses of 'legalism', then in what ways exactly is political jurisprudence still law?13 And third, most importantly: if political jurisprudence does indeed both require and facilitate a lasting commitment to openness, to contradiction, and to 'unresolvability', are the chances of sustaining public law's paradoxical logic in fact best supported by insisting on its secular and juristic qualities in the way Loughlin frames them?

\footnotetext{
${ }^{6}$ FPL, 465.

${ }^{7}$ E.g. FPL, 156 (quite literally 'forever': see the reference to 'perpetual conflict'). Safeguarding this essential openness to contradiction is Loughlin's only explicitly identified normative commitment (see at 13). Having framed his argument as - predominantly - an exercise in retrieval and reconstruction, Loughlin tells us almost nothing - at least in this work - about the connections between his notion of 'unresolvable confrontation' and broadly similar ideas in normative political philosophy, such as, most importantly, Rawls' overlapping consensus (for a brief allusion, see at 365). These possible linkages will also remain outside the scope of this response. I should note, though, that some of the work drawn on below in support of a critique of Loughlin - in particular that of the anthropologist Talal Asad and the political theorist William E. Connolly - is also, explicitly or implicitly, critical of Rawls. See further William E. Connolly, Why I Am Not A Secularist (University of Minnesota Press: 1999).

8 FPL, 11, 13.

${ }^{9}$ Cf. Jean-Pierre Dupuy, The Mark of the Sacred (Stanford: 2003), 17. Positing the 'universality' of any particular binary simply imposes at a meta-level a form of precisely the absolutism that Loughlin seeks to avoid.

${ }^{10}$ This emphasis on the double meaning of the verb is taken from Jean-Pierre Dupuy and Louis Dumont. See Dupuy (2003), 5.

${ }^{11}$ Hent de Vries, 'On General and Divine Economy: Talal Asad's Genealogy of the Secular and Emmanuel Levinas's Critique of Capitalism, Colonialism, and Money', in: David Scott \& Charles Hirshkind (eds.), Powers of the Secular: Talal Asad and His Interlocutors (Stanford: 2005), 131. See also Marcel Gauchet, 'Tocqueville', in: Mark Lilla (ed.), New French Thought: Political Philosophy 91 (Princeton: 1994), 103 ('the existence of the irreconcilable within society').

12 FPL, 231.

${ }^{13}$ FPL, 308.
} 
The argument offered in response starts from the claim that in his focus on retrieving and defending the autonomous and foundational character of public law in the modern age - after religion and against mere positive law, as it were Loughlin does not take either religion or law sufficiently seriously. This is to say that he does not treat them as discourses and fields with their own histories and practices, internal dynamics and forms of efficacy. Ironically, it is precisely because Loughlin develops such a richly nuanced understanding of the politicojurisprudential as a discursive modality - the register of a 'prudential discourse of political right' -, that the book's essentialising take on what are, at least to some extent, two parallel registers - of the religious and of the juridical - is so striking. ${ }^{14}$ The main reason for this flattening gaze may be that although both religion and law are assigned important, even crucial, roles in the narrative of 'Foundations of Public Law', these roles remain highly specific and circumscribed. This is where the relation to the third dimension of political jurisprudence noted above - its positive embrace of 'unresolvability' - becomes important. In more general terms, the principal danger to the vitality of paradoxes and of reflexive or dialectical relationships has to be some externally imposed form of closure. The main such threats of closure Loughlin identifies stem from what we might call two types of fundamentalism. There is, first, the more 'formal' fundamentalism of an exclusively positivistic and legalistic understanding of public law. ${ }^{15}$ And second, there is the more 'substantive' fundamentalism of absolutist religious ideas and values, and more recently, the perfectionism of what Loughlin calls 'the social'. Loughlin's public law, as the 'the ineffable idea of the jus of lex', then, must continuously resist attempts at re-grounding through either a 'purely formalistic notion' of law or through the 'importation of substantive values derived from natural law'.16

Intriguingly, it may well be that these two fundamentalist challenges, of legalism and value-absolutism, are related, and also that they are both of particular salience in the present moment. ${ }^{17}$ In a 2009 article, the anthropologist John Comaroff observed a 'simultaneous fetishism of the law and the assertive rise of religiosity in the age of neo-liberalism'. ${ }^{18}$ Part of what Comaroff means is that recent decades of intense juridification - of constitution-writing, of international human rights litigation, of investment arbitration, and so on - have also been a period of an increased significance of religious formations in the public sphere, notably in places like the United States, West- and North-Africa and the Middle

14 'Modality' is used here in the basic sense of a mode of engagement with the world. Cf. Adam B. Seligman, Robert P. Weller, Michael J. Puett \& Bennett Simon, Ritual and its Consequences: An Essay on the Limits of Sincerity (Oxford: 2008), $\mathrm{x}$.

15 FPL, 297.

${ }^{16}$ FPL, 232.

17 These parallels and possible relationships between positivism and value-absolutism are not addressed explicitly in the book. Nevertheless, in my view it is one of the achievements of Loughlin's work to furnish examples of these parallel movements and to stimulate reflection on their relationship. See also below, fn. [20].

${ }^{18}$ John Comaroff, Reflections on the Rise of Legal Theology: Law and Religion in the Twenty-First Century, 53(1) SOCIAL ANALYSIS 193, 194ff (2009). 
East. ${ }^{19}$ Comaroff also suggests, however, that these are not merely parallel movements, but that we are in fact witnessing different forms of the 'mutual infusion of law and religion'. 'Pace Carl Schmitt', he argues in response, 'it is not just about political theology that we ought to be vexing ourselves. It is also about legal theology'. ${ }^{20}$ One question motivating my commentary on Loughlin's work is whether taking 'legal theology' seriously, as the encounters and analogies, clashes and parallels, between the religious and the juridical, is something that 'Foundations of Public Law' does. My sense is that it does not. Rather, in his effort to answer a problem cast as political theology by way of political jurisprudence, it is not just religion, or law, but legal-, or juridical theology that becomes the missing leg in Loughlin's genealogical and conceptual triangles.

These parallel critiques of Loughlin's constricted views of religion and law, and of his neglect of their intertwined existence in juridical theology, occupy Sections II and III of this essay. Section IV then goes on to argue that the insistence on the secular and juridical character of political jurisprudence are, in fact, merely two aspects of a more general assertion of public law's autonomy, or more precisely: its immanence. Immanence is used here in the sense of Weber's 'Eigengesetzlichkeit - as the 'internal and lawful autonomy', of different spheres of life. ${ }^{21}$ Religion, when understood as absolute, comprehensive exteriority 'heteronomy', in Gauchet's terminology - threatens this autonomy. The juridical, taken as an instrument available for appropriation, supports it, while any danger posed by its own formal absolutism is seen as a threat that can be contained. Against this background, this Section discusses two related areas of difficulty.

The first concerns the idea of immanence itself. ${ }^{22}$ This theme arises because, in spite of the - perhaps partly polemical - emphasis on purely immanent logics in 'Foundations of Public Law', the character of droit politique as actually developed in the book does in fact rely on various forms of exterior authority, heteronomy, or indeed: transcendence. Key examples are the given-ness of language, shared conceptions of past and future, and especially, as described earlier, the character of the juridical form. These elements are in need of recognition and exploration. Not least because they offer suggestive parallels to some of the work Loughlin

\footnotetext{
${ }^{19}$ Comaroff, ibid.

${ }^{20} \mathrm{Ibid}$. Another way of capturing these parallel turns towards religion (and the assertion of religious identities in particular) and towards law, is by seeing both as part of an 'overwhelming concern with sincerity' that marks our age; with 'sincerity' understood as a "concern with "authenticity," with individual choice,' and by the projection of a 'totalistic, unambiguous vision of reality "as it really is." See Seligman et al. (2008), 8-9, 42, 118, 122-124 (emphasis in original); and further Section 4, below. A third, similar, diagnosis is offered by Alain Supiot, who decries the simultaneous phenomena of a 'flood of individual rights' (somewhat confusingly called 'legal nihilism'), and 'religious fanaticism' as two sides of the same 'temptation of fundamentalism'. See Alain Supiot, Homo Juridicus (Verso: 2007), xxi, xxv. These three perspectives - of legal theology, sincerity, and fundamentalism - differ in important ways, but they also share similar themes.

${ }^{21}$ Charles Wright Mills \& Hans Heinrich Gerth (eds.), From Max Weber: Essays in Sociology (New York: Oxford University Press, 1958), 328.

${ }^{22}$ FPL uses both 'transcendence' and 'exteriority', apparently as synonyms. 'Heteronomy' is used by Gauchet, but does not figure in FPL, despite the centrality of 'autonomy' to the book's argument.
} 
examines in his reconstruction of political jurisprudence, notably the writings of Jean-Jacques Rousseau.

The second area of difficulty concerns the relationship between immanence and irreconcilability as twin aspects of the character of political jurisprudence. On this point, I argue that Loughlin's rigid insistence on the immanent character of public law, in the end, undermines rather than strengthens the possibility of sustaining the kind of contained conflict he strives for. This argument draws together the understanding of religion presented in Section II, with an extension of Loughlin's own emphasis on paradox and ineffability, and it contains two claims. The first is that ritual may have an important role to play in safeguarding openness and contradiction. This may be counter-intuitive. Ritual, after all, is often associated rather with formalism, dogma, and cohesion. But recent anthropological work emphasises how ritualised action can also help defer closure and counteract the fundamentalism that comes with the 'drive to wholeness'. ${ }^{23}$ Through ritualised action, these anthropologists suggest, 'absolutes' imposed from outside, can be replaced with 'shared subjunctives' construed partly from within. More specifically, and this is my second claim, it is through such forms of acting that individuals and collectives may be able to construct and maintain vital pockets of 'in-betweenness'. ${ }^{24}$ This is space - mostly metaphorical and discursive, sometimes actual - that belongs neither entirely to the social, nor fully to any individual. Such sites can never be comprehensively occupied or represented by any person, any group, or by society itself. This means that, from the perspective of both individuals and the collective, they offer an empty space that appears as simultaneously immanent and transcendent. They are islands, in other words, of transcendence-within-immanence.

This emphasis on the significance of these themes, of 'unoccupiability', 'inbetweenness', and ritual, finally, suggests two important possibilities that 'Foundations of Public Law' does not admit. First, that the religious may not be a mere absolutist threat to public law, but could also, through its links to ritualisation, be supportive of public law's requisite open-endedness. ${ }^{25}$ And second, conversely, that the perils of legalism, so deeply embedded within the discursive modality of the juridical, may be far more difficult to contain than Loughlin seems to allow.

\footnotetext{
${ }^{23}$ Cf. Connolly (1999), 141, 143; Seligman et al. (2008). See further Section 4.

24 See further Section 4.

25 As should become clear below, this is a very different argument from the well-known claims developed by Tocqueville, Ernst Bockenforde, Robert Bellah, and others, on religion as a guarantor of social cohesion.
} 


\section{TAKING RELIGION SERIOUSLY: POLITICAL JURISPRUDENCE AS SECULAR}

In 'Foundations of Public Law', religion is both utterly central and curiously absent. The same is true for law, as I will argue in the next Section. These parallel absences have important implications for what Loughlin is able to say about the character of public law as a secular prudential discourse of political right.

Religion's centrality, first, is perhaps most immediately noticeable in the way the work of the French philosopher Marcel Gauchet quite literally bookends Loughlin's argument. ${ }^{26}$ It is Gauchet's grand narrative of the 'disenchantment of the world' that Loughlin turns to for an account of the dynamics of differentiation and separation said to underpin the emergence of an autonomous domain of the political. ${ }^{27}$ Gauchet also furnishes the timing of the relevant decisive historical change in outlook, with his claim that after 1700 the 'age of religion as a structuring force' of collective organisation 'is over'. ${ }^{28}$ More generally, Loughlin's thesis of a recent 'return of the religious, albeit in a different form' has a clear analogue in a depiction Gauchet offers, in his work on Tocqueville, of a twentiethcentury 'return of the religious principle', as 'the full and entire reconciliation of society to a predetermined truth' under totalitarianism. ${ }^{29}$ Most importantly, Gauchet's identification of a fundamental incompatibility between 'religion' and 'democracy' provides the template for the character of political jurisprudence itself. Religion, for Gauchet, means appeals to 'the external' and 'the absolute' as sources of authority - precisely the transcendence and the fundamentalism that Loughlin rejects. Democracy, in stark contrast, enables and organizes 'the existence of the irreconcilable within society'. ${ }^{30}$ Loughlin's public law, as noted before, then becomes the prudential public discourse that assures this essential unresolvability.

My claim in this Section is that by following Gauchet so closely, Loughlin commits himself to a historical and philosophical perspective that does not take religion seriously, in three related senses of that phrase. ${ }^{31}$

First, since Gauchet's original publication - and more particularly, during the decade or so leading up to Loughlin's book - there has been a sustained attack on the 'easy assumption' that public life today is 'basically secular'. ${ }^{2}$ This has been an

\footnotetext{
26 E.g. FPL 6-7; 48; 63; 84;103; 465.

27 FPL, 6-7; 63.

28 FPL, 48.

${ }^{29}$ FPL, 465; Gauchet, Tocqueville (1994), 106.

30 Ibid., 103, 108 ('The radical originality of democratic society ... is always to question itself'); FPL, 465.

31 See further Sarah Shortall, Lost in Translation: Religion and the Writing of History, 13 MODERN INTELLECTUAL HiSTORY 273 (2016).

32 Craig Calhoun, Mark Juergensmeyer, Jonathan Vanantwerpen, 'Introduction', in: Craig Calhoun, Mark Juergensmeyer \& Jonathan Vanantwerpen (eds.), Rethinking Secularism (Oxford: 2011), 3; Winnifred Fallers Sullivan, Robert A. Yelle, Mateo Taussig-Rubbo, 'Introduction', in: Winnifred Fallers Sullivan, Robert A. Yelle \& Mateo Taussig-Rubbo (eds.), After Secular Law (Stanford: 2011, 1); Martin Riesebrodt, Fundamentalism and the Resurgence of Religion, 47 NUMEN (2000), 266-287.
} 
extended scholarly moment of 'searching critique' for 'long-accepted discourses of modernity and enchantment', as well as for the teleological paradigms on which these tend to rest. ${ }^{33}$ Traditional periodisations - the idea of an 'enchanted' middle ages and the notion of a 'decisive cultural rupture' at the end of the $17^{\text {th }}$ Century as well as the conceptual vocabulary of 'secularization', 'secularism', and 'the secular' have all come to be seen as much less stable than assumed previously. ${ }^{34}$ Loughlin, however, continues to rely on a version of the classical narrative that is now among the most radical in the field, subscribing fully to the teleology of ' $a$ progressive and thorough modern secularization' of law. ${ }^{35}$ In 'Foundations of Public Law', history moves forward 'because of God's withdrawal' from 'a secularizing world'. And secularisation is a broadly coherent project, propelled by jurists actively 'undertaking' a 'transition to modernity'. ${ }^{36}$

Second, religion figures in 'Foundations of Public Law' in some sense as a 'transhistorical constant' - as 'an independent variable that affects other aspects of human life while itself eluding historical change'. ${ }^{37}$ This constancy is not immediately obvious. After all, religion disappears in an important sense in Louglin's account, only to resurface again 'in a different guise', later in modernity. But this narrative still incorporates an understanding in which, first, religion's role appears to be largely unchanging during the long period of its initial reign, and in which, second, there exists in fact some identifiable, deeper, underlying religious element that is capable of resurrection in some recognisable sense, even after a long period of absence. For the first part of this story, the long period of pre- and early-modernity, the book tells us virtually nothing about religion's character, content, form, or modes of efficacy, apart from the abovementioned references to 'the absolute other' as a form of authority. Religion, for Loughlin and Gauchet, as for Kant and Schmitt, is theology; and theology is dogma. ${ }^{38}$ But this abstract and

33 Michael Saler, Modernity and Enchantment: A Historiographic Review, 111 THE AmERICAN HISTORICAL REVIEW 692 (2006), 700; Alexandra Walsham, The Reformation and "The Disenchantment of the World" Reassessed, 51 The HistoriCAL JOURNAL 497 (2008), 504, 528.

34 Ibid. See also Fallers Sullivan et al. (2011), 2; Calhoun et al. (2011), 3 ('Until quite recently, it was commonly assumed that public life was basically secular'); Walsham (2008), 499 ('In recent years ... the notion that the Reformation was a powerful catalyst of the "disenchantment of the world" has been seriously questioned and qualified').

35 FPL, 84, 63. Gauchet's theory has been described as 'the only modern theory of secularization' to posit the 'disappearance' of religion. See Philip Gorski, Historicizing the Secularization Debate: Church, State, and Society in Late Medieval and Early Modern Europe, ca. 1300 to 1700, 65(1) AMERICAN SOCIOLOGICAL REVIEW 138, 141 (2000). This is even taking into account his concession of the survival of religion in 'the personal sphere', or as Loughlin puts it with a different emphasis, 'as culture'. Fallers Sullivan et al. (2011), 9. Note: In this respect, it is striking how much more Loughlin tells us about the historical settings in which his protagonists were writing than about the immediate context for his own theory. What Loughlin offers us is a theory of public law heavily invested in the idea of a secular, autonomous public sphere, at precisely the time when the notion of the 'demarcation' of religion from such a sphere, both as a historical occurrence and a present-day phenomenon, is increasingly uncertain. 36 Cf. FPL, 84.

37 Shortall (2016), 275. This theme is central to the work of Talal Asad. See, e.g., his Genealogies of Religion (Baltimore: Johns Hopkins University Press: 1993).

38 Cf. Graham Hammill, 'Blumenberg and Schmitt on the Rhetoric of Political Theology', in: Graham Hammill \& Julia Reinard Lupton (eds.), Political Theology and Early Modernity (Chicago: 2012), 87 (referring to Schmitt's discussion of Erik Peterson's 1925 essay 'What is Theology?', in his Political 
timeless conception cannot do justice to religion as a historical phenomenon. It can explain neither its earlier capabilities as a 'structuring force', nor why and how this efficacy would have been lost. It does not account for any variation in religious doctrines and practices or in their significance to individual and collective life. ${ }^{39}$ For the later part of the story, there is a second consideration, which is that if religion is to remain potent as a threat today, as Loughlin claims that it does, then it has to be 'more than just the obsolete vestige of a distant past'. 40 There apparently is, in other words, something underneath religion's changing appearance - 'the religious' - that is granted 'a transhistorical status that is denied to other historical formations - in particular social and political ones'. ${ }^{41}$ In a sense, this is a case of taking religion too seriously, by according it, as James Chappel has put it, 'a special reprieve from history'. ${ }^{42}$ This 'transhistorical constant' view of religion is commonly associated with the work of Alexis de Tocqueville. It is a view that is often criticised for its - explicit or implicit - attribution, to religion, of a positive, socially integrative force. 43 Tocqueville himself famously wondered 'whether man can ever support at the same time complete religious independence and entire political freedom', and was drawn to the conclusion that 'if a man is without faith, he must serve someone and if he is free, he must believe'. ${ }^{44}$ Loughlin and Gauchet, of course, draw the diametrically opposite conclusion: that true political freedom comes only with religion's demise, and the transition from transcendence to immanence - from heteronomy to Kantian autonomy, from an 'ordre subi, in Gauchet's terms, to an 'ordre voulu'. ${ }^{45}$

The structural parallel between these two positions prompts a third, related, critique: that 'Foundations of Public Law' ignores the internal dynamics and ambiguities within the field of religion, as well as the difficulties of imposing any clear boundary between religious and non-religious phenomena. In the world of 'Foundations of Public Law', it is always possible to identify an idea, a practice, or a

Theology II. See also Gauchet, Tocqueville (1994), at 98-99 ('intellectual constraint' coming from 'a body of dogmatic beliefs sheltered from the disputes of experience').

${ }^{39}$ Note: Where Gauchet writes of the central importance of the development of 'the State', he means to refer not just to the development of nation States in Western-Europe that Loughlin has in mind, but also to the very first instances of public administration, found around 3000 B.C. See, e.g., Marcel Gauchet, Le Désenchantement du Monde (1985), at 20 ('l'emergence de l'Etat ... comme l'evenement majeur de l'bistoire bumaine', refers to 'quelque part autour de 3000 avant J.-C. en Mesopotamie et en Egypte', see 22). See also 21: 'cinquante siècles de politique contre la religion'). For criticism, see also Martin Riesebrodt: 'by placing the seeds of secularization into the rise of the early empires, secularization becomes the logical outcome of the reconfiguration of religion as soon as the paradise of "primeval" society is lost' (Martin Riesebrodt, Book Review, in ASJ 1999, 1526).

${ }^{40}$ Cf. Shortall (2016), 279 (discussing opposite, but structurally identical, claims as to religion's continued relevance).

${ }^{41}$ Ibid. For this perspective see, e.g., FPL, 19 (raising the question of 'to what extent to religious and symbolic impulses ... continue to permeate our subject?'; describing 'theological questions' in abstract terms as 'driven by an appeal to the power of the One, and the need to mediate both between the visible and the invisible, and between the temporal and the eternal'; and remarking that 'the extent to which these impulses live on in the guise of new beliefs and representation remains in question today').

42 Cited in Shortall (2016), 275.

43 Ibid. (discussing the work of Brad Gregory).

${ }^{44}$ Tocqueville, 2.I.5, p. 512.

45 Gauchet, Le Désenchantement du Monde (1985), 15. 
form - most broadly: a discourse - as 'religious' or not. The same goes for the identification of discourses as 'juristic', on which more below. But precisely what it is that makes a discourse 'religious' - or 'juristic' - is nowhere explained. And any attempt at such an explanation is bound to run into serious difficulty. To begin with, recent historiographical scholarship has emphasised striking instances of the 'heteronomous intellectual practices of the early modern period'. ${ }^{46}$ This work effectively undermines the notion of any clear historical and conceptual break - a 'great separation' - between ostensibly secular discourses of politics and law on the one hand and religion on the other, during that time. ${ }^{47}$ Of special relevance for Loughlin's genealogy in this regard are the writings of Thomas Hobbes. For Hobbes, in a nuanced reappraisal by the historian Jonathan Sheehan, "theology" and "law" were equally potent schemes for thinking [the] containment' of the commonwealth, and its preservation in the face of disorder and disintegration. ${ }^{48}$ Even more fundamentally, what emerges from this reassessment, as Sheehan explains, is that 'theology, like politics, is not an essence, but a set of claims that appear in time'. ${ }^{49}$ This idea, that religious utterances and symbols 'cannot be understood independently of their historical relations with nonreligious symbols or of their articulations in and of social life', is central to the work of the anthropologist Talal Asad. ${ }^{50}$ In his well-known critique of Clifford Geertz's symbolic approach to religion, Asad has called for attention to the 'authorizing processes', of power and discipline, by which religious meaning is constructed in the world. ${ }^{51}$ '[T] he theoretical search for an essence of religion', Asad writes, 'invites us to separate it conceptually from the domain of power'. ${ }^{52}$ And it is through power, in a wide range of forms - including worldly and ecclesiastical laws, sanctions, and the disciplinary activities of social institutions and of individual bodies - that in Asad's view, "“religion" is created'. 53 Even if one does not accept this critique in its most stringent version, it is easy to see how attention to the diverse range of processes by which religious meanings are created is bound to throw up all kinds of difficult boundary questions. Questions, that simple binary oppositions - between religion as a powerful structuring force of collective organisation and religion as mere culture, or between religion as domesticated culture and religion as recurrent threat - cannot adequately address.

\footnotetext{
${ }^{46}$ Jonathan Sheehan, 'Assenting to the Law: Sacrifice and Punishment at the Dawn of Secularism', in Fallers Sullivan et al. (2011), 73.

${ }^{47}$ For the term 'the great separation', see Mark Lilla, The Stillborn God: Religion, Politics, and the Modern West (New York: Knopf, 2007).

48 Sheehan (2011), 73. See also Walsham (2008), 511 ('English monarchs continued to be seen as conduits of thaumaturgic power').

${ }^{49}$ Sheehan (2011), 77.

50 Asad, 'The Construction of Religion as an Anthropological Category', in Genealogies of Religion: Discipline and Reasons of Power in Christianity and Islam (Baltimore: Johns Hopkins University Press, 1993), 53-54.

${ }^{51}$ Ibid.

52 Ibid., 29.

53 Ibid., 37.
} 


\section{AUTONOMY AND AMBIVALENCE}

Two main reasons animate this extended discussion of the position of religion in 'Foundations of Public Law', and of the book's position in the wider contemporary landscape of secularisation scholarship. I should emphasize that these go beyond highlighting the disjunction in Loughlin's work between, on the one hand, an acknowledgment of the fuzziness of any boundaries between the medieval and the modern, or the sacral and the secular, and, on the other, the centrality of precisely such a break, in conceptual terms, for his overall project. ${ }^{54}$ They concern rather, first: the possibilities for a historicised and comparative understanding of the idea of 'autonomy' in general, in order to better grasp the notion of autonomy of the political more specifically; and, second: the appreciation of the irreducibly ambivalent character of religious phenomena, in contrast to the one-dimensional emphasis on the-absolute-as-constraint, emphasised by Gauchet and Loughlin.

First, as mentioned earlier, Loughlin is deeply invested in the idea of autonomy for the public sphere. That autonomy is closely interwoven with supported by and generative of - a highly distinctive and similarly autonomous notion of specifically political power. Now, one thing Asad's work does is to show how historiographical and conceptual questions concerning the elaboration of this political autonomy find important parallels in the construction of an analogous autonomy for religion. Religion itself, in other words, comes to be included in the list of domains for which the construction of their - relative - autonomy needs to be interrogated. That perspective is radically different from the classical differentiation account, followed by Loughlin, in which religion figures merely as a background out of which modern specialised domains, like literature or art or science, and of course politics, emerge. 55 The relevant shared question is succinctly raised by the editors of a collection on 'Political Theology and Early Modernity', which appeared around the same time as Loughlin's book. 'How does politics remain distinct from the content and practices of ethics, economics, and culture, while nonetheless bearing on them', these editors ask, 'and how does politics share this difference with religion'?56 By casting religion merely as shackles to be thrown off, Gauchet, and following him, Loughlin, foreclose an important avenue for exploring precisely this type of question. For the editors of the political theology collection, 'grasping what is distinctive' about religion and, in their example, art, as 'forms of human expression' requires 'some kind of formal and phenomenological accounting'. ${ }^{57}$ This kind of formal analysis of course lies at the heart of 'Foundations of Public Law', and Loughlin's own earlier 'The Idea of Public Law'. Curiously, however, this approach only extends to the domain and the discourse of political

\footnotetext{
54 See, e.g., FPL, 17.

55 See, e.g., FPL, 7.

${ }^{56}$ Hammill \& Reinhard Lupton (2012), 4 (emphasis added).

57 Ibid., 6. For a similar perspective, see Shortall (2016), 284 (calling for 'an appreciation of the way in which religious discourses interact with, but are not exhausted by, the political, social, and cultural contexts of their production').
} 
jurisprudence; not to religion, nor, as I will claim below, to law. But attending more carefully to the way religious phenomena come to be authorised as religious, as well as to the roles of power and discipline in the construction of the category of 'religion' and the differentiation of the domain of 'the religious', is bound to be significant for a project so invested in a parallel autonomy for the political. ${ }^{58}$ Without such a comparative and relational approach, it will be difficult to move beyond mere assertions of differences between a 'secularization of power' and a 'transfusion of sacrality into politics', for example, or between divine grace as 'bolstering' as opposed to 'creating' a sovereign's status. ${ }^{59}$ And our understanding of the idea of 'autonomy' is likely to remain ahistorical and importantly incomplete. ${ }^{60}$

Second, there is the problematic association of religion with the idea of the absolute. It is important to re-emphasise that the secularisation narrative described earlier has a central role to play in Loughlin's story. Secularisation and secularism render necessary, enable, and ultimately determine the character of, an antifoundationalist conception of the foundations of public law. Secularisation provides the narrative in which the reign of absolute values, externally imposed, is replaced by a public discourse in which everything is always and continually up for prudential revision in a debate among equal participants. On this view, then, religion can only ever be understood as the absolute and the external - the 'absolute other' in Gauchet's phrase. ${ }^{61}$ And religious power only ever works to constrain, as opposed to the rules of public law, which always simultaneously, and paradoxically, both enable and restrict. ${ }^{62}$

This story, however, ignores a diametrically opposite view of religious discourses and their social efficacy. Like Loughlin's and Gauchet's account, this alternative view has its roots in both history and philosophy. But instead of a onesided emphasis on religion as constraint, this view stresses rather 'the irreducibly ambiguous ways in which religious discourses operate historically, at once constraining and enabling their subjects'. ${ }^{63}$ Adopting a historical understanding of theology 'not as a passive entity or thing, but dynamic process', this view emphasises that 'ambivalence and contradiction', doctrinal tension and disagreement, 'should not be regarded as anomalies but normalities'. ${ }^{64}$ On this reading, any association between religion and absolutism becomes contingent rather than necessary, certainly as a matter of history. Going further, the

\footnotetext{
58 Also because it will show how 'political' forces have long been bounded up with the demarcation of 'religious' spheres. See, e.g., Walsham (2008), 522 (noting, for example, how 'political, rather than intellectual, forces' were significant in provoking a 'loss of credibility' for demonology and witchcraft during the early-modern period).

${ }^{59}$ For a more detailed discussion of examples of such 'migrations of the holy', see Walsham (2008), esp. at $111 \mathrm{ff}$.

60 See FPL, 39 for these references.

61 Gauchet, Tocqueville (1994) 108.

62 See, e.g., FPL 178. E.g. Gauchet, Tocqueville (1994), 110 (religion as 'ultimate limits').

63 Shortall (2016), 281. See also 275 (noting 'he political ambivalence of religious phenomena: the way they function as sites of empowerment as well as constraint, and inclusion as well as exclusion').

64 Walsham (2008), 527.
} 
philosopher of religion Hent de Vries has argued that what he calls 'dwelling in contradiction' - and what Loughlin might call living with, or in, paradox - 'is the "modality" of the spiritual life, the religion of adults'. Now, whether, with de Vries, one sees this kind of radical openness as the core characteristic of religion 'always and everywhere' -, or whether one adopts a more moderate view, allowing at least as much room for contradiction as one does for dogma, and for empowerment as for constraint; in both cases, any equation of religion with the absolute dissolves. In fact, on the more moderate view, religion, as both enabling and limiting, as pushing towards universality and as a 'destructuring movement away from unity', comes to resemble very closely the character of political jurisprudence as described by Loughlin. The religious, like the political - even as an inflection of the political, perhaps -65 rather becomes available as one more resource, conceptually and historically, for developing precisely the kind of prudential discourse for life lived in common, in contradiction, that Loughlin cares about.

\section{TAKING LEgalism SERIOUSly: Political JURISPRUdenCE AS LAW}

The notion that political jurisprudence, as a 'prudential discourse of political right', must be a juristic discourse, is as central to Loughlin's account as the idea that public law must be a secular phenomenon. But what is it, precisely, that makes a discourse 'juristic'? What, in other words, makes public law, law? That, in 'Foundations of Public Law', is far less clear. This is not for want of invocation of the appropriate terms. The autonomy of the public sphere, Loughlin says, is 'sustained by its own politico-legal norms and practices'. ${ }^{66}$ These norms and practices - droit politique - form a 'singular type of juristic discourse'. ${ }^{67}$ Its vision of the 'rightordering of public life' is a juristic concept'. 68 It obeys to a 'juristic logic' and offers a 'juristic frame' for political judgment. ${ }^{69}$ It cannot, of course, be the aim of this Section to restate or clarify what Loughlin means by 'public law' in the broader sense of 'Recht' or 'droit', as elucidated by Hegel and Rousseau, and so many other writers in the long Western tradition that 'flourished from the late-sixteenth to the early-nineteenth centuries'.70 That, after all, is what 'Foundations of Public Law', as a whole, is about. What I am rather concerned with here is the insistence that this tradition is concerned with 'a category of juristic thought'. ${ }^{71}$ Especially because Loughlin is equally insistent that the vitality and significance of this category of thought depend entirely on it also being something else, something more, than just positive law. ${ }^{72}$

\footnotetext{
65 De Vries, On General and Divine Economy (2005), 131.

66 FPL, 86-87.

67 FPL, 231.

${ }^{68}$ FPL, 159 (in an account of 'authority').

${ }^{69}$ FPL, 237, 400.

70 FPL 9; $111 \mathrm{ff}$ (on Rousseau).

71 FPL, 9.

72 Among many instances, see, e.g., 237 (discussing Heller).
} 
These terms - 'juristic', and 'legal', in particular - are nowhere defined. As was the case with 'religion' in the previous Section, and again in marked contrast to the great care taken to elaborate the character of droit politique itself, the identification of phenomena as 'juristic', and of actors as 'jurists', is simply taken as given. The book does, however, offer a number of indirect, partial answers. Juristic, to begin with, references a 'rationalist commitment.$^{73}$ Law brings with it ideas of order and regularity, often by analogy with laws of nature, and a sense of 'scientific discipline..$^{74} \mathrm{It}$ is associated with the Hobbesian idea of command.75 Juristic accounts are concerned with the constitution of authority. ${ }^{76}$ They are normative, in that they are not merely backward-looking historical investigations, but are concerned also, at least in part, with ideals. But juristic also carries the meaning of practical, in the sense that law is dynamic, but also in the sense that juristic accounts are concerned, at least in part, with social reality, rather than merely operating on the level of political philosophy or morality. ${ }^{77}$ Juristic, finally, also appears as a simple shorthand for secular.

We get a particularly clear idea of the kinds of commitments involved in the adoption of a juristic frame, in Loughlin's discussion of Tocqueville's views on the role of lawyers in American democracy. For Tocqueville, lawyers, by their training, acquire 'certain habits of order, a taste for formalities, and a kind of instinctive regard for the regular connection of ideas, which naturally render them very hostile to the revolutionary spirit and the unreflecting passions of the multitude'. ${ }^{78}$ 'Without this admixture of lawyer-like sobriety with the democratic principle', Tocqueville continues, 'I question whether democratic institutions could long be maintained'. ${ }^{79}$ These passages, both quoted in 'Foundations of Public Law' raise two rather different questions. The first, to be discussed only briefly here, concerns the tension between, on the one hand, the book's embrace of these limits on democracy set by 'lawyers and legal modes of thinking', and, on the other, its forceful rejection of apparently very similar limits on the 'political world' set by the 'spirit of religion' that Tocqueville also sees as indispensable. ${ }^{80}$ Here, it seems Loughlin could offer at least two defences. He might argue, first, that this inconsistency is only apparent, since the boundaries set by 'lawyers and legal modes of thinking' operate on the level of 'culture', and his account fully accepts that religion 'lives on as culture' in modernity, even when it has lost its efficacy as a 'structuring force' in society. In part for the reasons discussed in the previous Section, however, I do not think this binary distinction between 'mere culture' and something supposedly altogether more foundational can be maintained.

\footnotetext{
73 FPL, 98, 307.

74 FPL, 110, 73.

75 FPL, 88.

76 FPL, 159.

${ }^{77}$ FPL 112 (in contrast with pure political philosophy).

78 Cited in FPL, at 307.

79 Ibid.

${ }^{80}$ FPL 308-310; Tocqueville, Democracy in America (G.E. Bevan, trans.) (London, Penguin Books, 2003), $55-56$.
} 
Alternatively, Loughlin might say that the two kinds of boundaries are fundamentally different in that the juristic is entirely immanent, whereas the religious relies on some form of transcendence. This argument, and the understandings of immanence and transcendence it depends on, will be taken up in the next Section.

What I want to focus on here is a second question raised by Loughlin's embrace of Tocqueville's view of law and lawyers. This is the question of the prospects for a political jurisprudence that is able, in the longer run, to capture the benefits of the juristic form, without falling prey to the legalism that constitutes the flip side of that very form. Loughlin's invocation of law, it should be emphasised, is entirely instrumental. The 'form of law' is what invests the political discourse of right ordering 'with rational form, i.e. with universality and determinacy', so as to become the opposite of mere individual 'subjective conviction'. ${ }^{81}$ But while political jurisprudence relies on this juristic form, it is simultaneously threatened by 'legalism' and 'the triumph of ordinary law'.82 I am much less certain than Loughlin appears to be, however, that these dangers can be kept at bay. Does not invoking law - the juridical form, the authority of lawyers mean that we get all of law? This, I would argue, is what taking law seriously, as a form and as a discursive field with its own internal dynamics, suggests. Loughlin's discussion of the State shows this very clearly. The concept of the State, Loughlin argues, 'is the entity that gives us access to the nature of modern political reality and provides the key to understanding the nature of public law. It forms a scheme of intelligibility (...)'. ${ }^{\prime} 3$ But of course, as Loughlin also recognises, this scheme itself, this 'comprehensive way of seeing, understanding, and acting in the world', is itself an intellectual construct, of a very particular kind. ${ }^{84}$ And as Pierre Bourdieu writes, it must be impossible to give a genealogy of Western society without bringing in the determining role of jurists brought up on Roman law, capable of producing this fictio juris (...). The state is a legal fiction, produced by lawyers who produce themselves as lawyers by producing the state'. ${ }^{5}$ The way these lawyers have created this fiction - and, with it, themselves as a professional class, as recognised also by Tocqueville - is through what Bourdieu calls 'the imposition of form'. 86 That form, for all Loughlin's protestations that 'law' here should refer to 'public law' in his broader sense, is the Western legalist form, of ruleness and autonomousness. And that form also, whether for political, social, or metaphysical reasons, has a force of its own. A force that, as the anthropologist Harry Walker argues in recent work, often 'exceeds people's capacities to manage or control it'. 'Like magical power, it surpasses the intentionality of even the most potent

\footnotetext{
${ }^{81}$ FPL, 148, quoting Hegel.

82 FPL, 297.

${ }^{83}$ FPL, 208.

${ }^{84}$ FPL, ibid.

${ }^{85}$ Pierre Bourdieu, On the State: Lectures at the College de France, 1989-1992 (Cambridge, Polity Press, 2014), 55.

${ }^{86} \mathrm{Ibid} ., 57 \mathrm{ff}$.
} 
practitioners'. ${ }^{87}$ Loughlin's instrumental invocations of the juridical form do not take these fetishistic qualities into account. ${ }^{88}$ If law is invoked to rationalize and stabilise a political discourse meant to remain prudential, its form will also push towards closure. If law is relied on to maintain a political discourse meant to remain open and diverse, the juridical form will also impose centralisation. ${ }^{89}$ Even if the conceptual vocabulary of law is invoked because, after the supposed demise of religion, we have no other words left to express the kind of amalgam intended, of rationality, universalism, normativity, authority, etc., we have to realise that this juristic vocabulary is not innocent. ${ }^{90}$

In closing this Section, it is necessary to acknowledge one last issue, which bears on the consistency between the perspective adopted here, on law, and the one developed in the previous Section, on religion. This is the question of whether 'juristic' and its cognate concepts and terms will have meant roughly the same thing to all the actors on the long historical arc traced in Loughlin's book. Is arguing that the juristic form will bring with it certain inherent tendencies that may overwhelm both individual and collective actors not akin to adopting the 'historical constant' view criticised earlier for religion? This is a difficult question, and one that cannot be fully answered here. It does seem at least plausible, however, that law and religion are different on this point, at least in the Western tradition. ${ }^{91}$ This is because the long arc of that tradition is itself built around, and constantly propagates, the idea of law as a historically constant form. The notions of law as a 'self-sustaining system of rules defined by reason'; of the legal order as 'separate and specialized technique of governing social relations'; and of legal science as 'an analytical approach to power and its rational normalization'; all have their foundation in Roman law.92 These were all notions that Loughlin's protagonists were familiar with; they often in fact invoked Roman law legal terms for these very qualities. And so, the danger that references to historical actors as a 'jurist', or to historical sources as law (lex) will be a-historical, therefore, seems considerably smaller than the corresponding danger for references to, say, the authority of an early-Modern monarch as being 'secular' in nature. ${ }^{93}$

\footnotetext{
87 Harry Walker, Justice and the Dark Arts: Law and Shamanism in Amaronia, 117(1) AMERICAN ANTHROPOLOGIST 47, 55 (2015). The argument here is not that no individual jurist can master all of law, but rather that invoking legal forms may bring consequences that surpass the intentionality of legal practitioners, both individually and collectively.

88 Cf. Walker (2015); Comaroff (2009); Christopher Tomlins \& John Comaroff, “Law As ...”: Theory and Practice in Legal History, 1 UC IRVINE L. REV. 1039 (2011).

89 Walker (2015), 55.

90 It is noteworthy, finally, that the basic question of why Loughlin's protagonists of political jurisprudence turned to law at all is never raised or answered in FPL. Compare in this regard, Ian Williams's recent observations in his review of Daniel Lee's Popular Sovereignty in Early Modern Constitutional Thought. '[A]n important question was begged and never addressed: why use legal material, language and ideas at all? Not all early-modern theorists did. Did legal material determine the issues raised and conclusions reached, or was it used instrumentally, justifying conclusions reached (or sought) for other reasons?'. See 80(2) MODERN LAW REVIEW 382.

91 But for an important caveat, see Tomlins \& Comaroff (2011), 1069.

92 See Aldo Schiavone, The Invention of Law in the West (Harvard University Press, 2012), 11, 13, 12.

93 Ibid., 201.
} 


\section{TAKING EXTERIORITY AND IRRECONCILABILITY SERIOUSLY: RITUAL AND THE 'IN-BETWEEN'}

Loughlin, then, presents political jurisprudence as a resolutely immanent phenomenon - a discourse free from any form of exteriority. Medieval government may have 'received its authority from transcendent source'. But the authority of modern government is firmly 'located in immanent necessities'. ${ }^{94}$ The break between these two perspectives, for Loughlin, following Gauchet, is what constitutes 'the deepest ever fracture in history'. ${ }^{95}$ Throughout this essay, I have sought to argue that such a categorical distinction, between immanence and transcendence, cannot be maintained. Section II questioned the idea that the religious is entirely outside or above the control of individuals and collectives, notwithstanding Gauchet's and Loughlin's strident portrayal of 'the essence of religious thought' as 'the external' and 'the unchangeable'. ${ }^{96}$ As historiographical and anthropological work shows, religion is simply too enmeshed with different forms of power and discipline to be understood as entirely transcendent in such a sense. Section III, in turn, sought to cast doubt on the idea that law, even when 'acknowledged to be a human construct', is entirely within human control. ${ }^{97}$ Law's hypostatised character and its fetish-like qualities render such pure immanence implausible.

Both religion and law, rather, appear as phenomena that are 'neither completely autonomous, nor completely constructed'.98 Taken together, these discussions of religion and law in fact suggest that, at least for such domains of individual-making, collective-making, and meaning-making, it may be impossible to draw any general distinction between immanence and transcendence in the first place. ${ }^{99}$ Once identified, this basic ambivalence turns out to pervade other elements of Loughlin's account of public law as well. The role played by language in Foundations is a good example. Recall that, for Loughlin, the discourse of political right is 'a language' needed for communication over matters of common existence. Loughlin links this formulation to Charles Taylor's similar notion of the need for a language to sustain a 'common space of evaluation' among individuals. ${ }^{100}$ Taylor importantly argues that such a language cannot belong to any one individual speaker - it must, as he writes, be 'our language'. And as such, he concludes, it 'has to be constituted by conversation between us'.101 This is surely a major insight, as Loughlin also acknowledges. But it does not fully capture the

\footnotetext{
94 FPL, 7.

95 Ibid., cit. Gauchet (1997), 28, 55. For the original French, see Gauchet (1985), 83-84, 157.

${ }^{96} \mathrm{cf}$. FPL, 6-7.

${ }^{97}$ FPL, 7.

98 Bruno Latour, On the Modern Cult of the Factish Gods (Durham NC, Duke University Press, 2011), 8.

${ }^{99}$ Cf. ibid., 28.

100 FPL, 155.

101 Charles Taylor, Hegel's Ambiguous Legacy for Modern Liberalism (1988) 10 CARDOZO LAW REviEW 865, cited in FPL, at 155.
} 
extent to which such a language, its terms and its structures, will also already have to exist prior to any particular conversation. ${ }^{102}$ Rather than being a purely immanent phenomenon, then, language combines all these elements in itself - of agency, both individual and collective, but also of heteronomy, or transcendence, as something both 'within us' and 'outside us'. ${ }^{103}$

The same basic ambivalence that is central to the character of religion, of law, and of language generally, I want to suggest, also marks the character of the special language of political right. While the rules of the grammar for this language are indeed, as Loughlin writes, 'rules that we have devised', that cannot be all they are. ${ }^{104}$ The discourse of public law as political jurisprudence is something we have built, but also that goes beyond us. ${ }^{105}$ That political jurisprudence may indeed be best understood in such a paradoxical, dual sense is suggested by the work of the originator of the term droit politique: Jean-Jacques Rousseau. When Rousseau writes 'il faudroit [sic] des Dieux pour donner des loix aux hommes', 106 he is not signalling some manifest impossibility, as perhaps suggested more strongly by his other famous aphorism, that placing 'law over man' would be akin to attempts to 'square a circle'. ${ }^{107}$ Instead, Rousseau goes into great detail to set out the requisite qualities of his Legislator as a figure straddling the immanence-transcendence boundary. 108 In one especially revealing formulation, Rousseau writes that for a people to come to be truly ruled by law it would be necessary that 'l'effet pût devenir la cause': 'that men should be before the law, what they are to become by the law'. 109 This is precisely the kind of paradoxical and reflexive dynamic that Loughlin emphasises throughout Foundations, as part of the distinctiveness of political jurisprudence. But the fact that the reversal of cause and effect that Rousseau invokes is a signature characteristic of the logic of fetishisation, suggests that more is involved here than the fully immanent idea of 'reflexivity' that Loughlin invokes. ${ }^{110}$ Instead, I would argue, following Jean-Pierre Dupuy, that what Rousseau's work demonstrates is the uncanny ability of human societies to 'produce their own exteriority'. ${ }^{111}$ These

\footnotetext{
102 For a broad statement to this effect, see Supiot, Homo Juridicus (2007), 7 ('We are all subject to the heteronomy of language. It constitutes the condition of any discussion and thus cannot itself be debated'). See also FPL, 31 (on the role of Latin).

103 See Roy Rappaport, Ritual, Religion and the Making of Humanity (Cambridge: 1997), 49 (citing Stanley Tambiah). See also Bourdieu, On the State (2014), 45 (on language as a 'repository of social philosophy'). 104 Cf. FPL, 178.

105 Cf. Latour (2011), 16.

106 Jean-Jacques Rousseau, Du Contrat Social (1762), II, 7 (Oeuvres Complètes La Pléiade III, 381). 107 FPL, 132.

108 Contrat Social, II, 7; OCP III, 383 ('Ainsi l'on trouve à la fois dans l'ouvrage de la Législation deux choses qui semblent incompatibles: une entreprise au-dessus de la force bumaine, \& pour l'exécuter, une autorité qui n'est rien'.). See for a subtle characterisation of the 'volonté générale' as 'à la fois immanent et transcendent', Lucien Scubla, 'Est-il Possible de Mettre la Loi au dessus de l'Home? Sur la philosophie politique de Jean-Jacques Rousseau', in Jean-Pierre Dupuy (ed.): Introduction aux Sciences Sociales (Ellipses: 1998), 131. For Scubla, the general will is based on a 'common interest', formed through the simultaneous exclusion of all individual interests - a common interest, therefore, at once within and outside all citizens, rather than some generalised aggregation of all their individual preferences (ibid.).

109 Contrat Social, II, 7; OCP III, 383. See also Scubla (1998), 134. Own translation, emphasis added.

110 Cf. Bourdieu, On the State (2014) 32; FPL 12, and many other instances.

111 Dupuy (2013), 2.
} 
are forms of projected exteriority, however, that are essentially ambivalent: they involve forms of 'self-exteriorization', or, in Dupuy's terms, 'selftranscendence'. ${ }^{112}$

One way of framing this argument is as a simple extension of Loughlin's own approach. If paradox lies at the very foundations of the public sphere, why would this same feature not also constitute that sphere as simultaneously immanent and transcendent, with boundaries at once firm and permeable, determinative of its identity and endlessly to be negotiated? We can also put this the other way around: It could well be that this reflexive and ambivalent conception of the relations between the register of political jurisprudence and alternative modalities, offers the best chance of securing the kind of commitment to openness and paradox that Loughlin seeks to maintain within public law. And so, the questions we should be asking would be the following. First, if some form of exteriority is unavoidable, is there any way to think through its character as something that is fundamentally different from the ideas of 'the absolute' and 'the unchangeable' decried by Loughlin? And second, if there is a way to conceive of exteriority in such a way, what does this mean for the character of public law and our approach to its understanding? The answers I would like to suggest to these questions - in the form of and 'ritual' and the 'in-between' - are developed, tentatively, in the remainder of this Section.

\section{RITUAL AND ‘IN-BETWEEN’ SPACES}

The project, then, is to take Loughlin's search for a discourse of public law that can ward of any form of absolutisation in the public sphere largely on its own terms, with the friendly amendment that the role of contradiction and ambivalence should be extended to the boundaries of that sphere itself. What would be the characteristics of such a discourse?

It seems that certain conceptions of ritual and ritualisation are particularly well suited to the kind of engagement with irreconcilability that Loughlin envisages. This argument begins with a view of ritual as one particular 'modality' of engagement with the world, rather than any 'discrete realm' of action. ${ }^{113}$ That, I would suggest, may also be the most productive way of thinking about public law (as well as about law more generally, and religion, but this is beyond the scope of this paper). At least on some views, one important characteristic of the modality of ritual - and of the practice of ritualisation - is that, using an unavoidably ugly term, it 'precises ambiguities, it neither overcomes them nor relaxes them'. 114 As the authors of 'Ritual and its Consequences', a collective essay written around the time of Loughlin's book, argue, 'the ritual mode has a built-in ability to abide with the inevitable ambiguities of life, even within an equally inevitable impulse toward an

\footnotetext{
112 Ibid., 9, 15.

113 Seligman et al. (2008), $\mathrm{x}$.

114 Ibid., 7, citing Jonathan Z. Smith.
} 
ever delayed - yet also never abandoned, desire for wholeness and totality'.115 What makes this suggestion especially interesting is the fact that these authors appear to share a diagnosis of a cultural, political, and social climate of around the turn of the $21^{\text {st }}$ century, that seems close to the one animating Loughlin's exercise to retrieve a lost discourse for the prudential negotiation of the tensions of common existence. 'The reaction to the cultural and economic forces of globalisation, the re-emergence of religious commitments and ethnic identities throughout the world', these authors argue, 'all suggest the failure of our existing cultural resources to deal with ambiguity, ambivalences, and the gentle play of boundaries that require both their existence and their transcendence'.116 Ritual preserves and emphasises ambiguities and tensions, such as those between tradition and innovation, between agency and submission, between different roles of individuals, and between the individual and the collective. The ritual mode is able to achieve such states of "dwelling in contradiction" through the creation of 'shared subjunctives'. These are 'as if worlds' of 'social convention and authority beyond the inner will of any individual'.117 For the authors of 'Ritual and its Consequences', 'what constitutes society - what makes the social a sui generis entity, irreducible to any other - is (...) a shared "could be", the "mutual illusion of the sort that all rituals create'.118 It is important to note that this 'subjunctively shared arena' is a 'space in between. It is not a place where individual entities dissolve into a collective oneness', of the kind Durkheim designated through his notion of 'effervescence'. 119

This last point is important in relation to the other question raised earlier, of how to understand exteriority in a way that sustains rather than abrogates productive tension and contradiction. Recall that Loughlin defines 'the social', as a principal danger to the vitality of political jurisprudence, as absolute and comprehensive claims of the right and the true. Such overriding claims, of course, do feature prominently in contemporary public discourse, and they may well be on the rise, as Loughlin suspects. Here, however, is a portrayal of 'the social' in terms of a shared 'could be': as the diametrical opposite of any 'totalistic, unambiguous vision of reality "as it really is". ${ }^{120}$ This, in other words, is 'the social' as tentative, fragmented, and always provisional, rather than in any sense 'absolute', or 'unchanging'. An alternative form of exteriority now also comes into view. What political jurisprudence - through ritual - may be able to do, I would suggest, is to actively construct, by way of a shared imagination, a kind of transcendence-within-

\footnotetext{
115 Ibid., 112; See also at xi ('a unique way of accommodating the broken and often ambivalent nature of our world'. Other writers in anthropology who have also highlighted connections between ritualisation and ambivalence and contradiction include Victor Turner and Vincent Crapanzano. For a general discussion, see Catherine Bell, Ritual: Perspectives and Dimensions (Oxford: 2009), 39-40, and 57. For a normative defence of a political philosophy with very similar features, see Connolly, Why I am Not a Secularist (1999).

116 Ibid., 10.

117 Ibid., 7, 11, 20.

118 Ibid., 23.

119 Ibid., 26 (emphasis added).

120 Ibid., 8.
} 
immanence: a space that 'belongs neither to the self nor the other'; neither to the individual, nor to the collective. ${ }^{121}$ These 'in-between' spaces are public law's exteriority within itself. And their constitutive feature is precisely that they are not marked by any definite substantive content, person, or group, but by a form of absence. What political jurisprudence sustains and protects, then, are pockets of emptiness: 'in-between' spaces that cannot be occupied by any individual speaker, or by any set of substantive values, and that cannot be entirely subjected to rules, or legislated away. ${ }^{122}$

Further development of the character of these 'in-between' spaces, and their logics of $u n$-occupiability and $u n$-representability, has to remain beyond the scope of this essay. ${ }^{123}$ For now, a helpful analogy can be found in the way ritual liturgies are similarly able to instil shared experiences of 'time out of time'. These are intervals during which one form of time - 'sacred' time, or 'festival' time, for example - is marked off from, moves differently from, but also remains dependent on, 'ordinary time'. 124 During such periods of transcendence-within-immanence, contradictions can be played out rather than definitely resolved. This is also how I would characterise the space for confrontation opened up, ideally, in political jurisprudence. It is also worth noting that these themes find resonance in broader anthropological, historical and philosophical writing. ${ }^{125}$ Take for instance, this interpretation of the famous 'empty throne' of the Ashanti in the work of the anthropologist A.M. Hocart: '[F]or a limited time the chief of state will occupy an inviolable place. Like the king of the Ashanti, who sits under [his throne] because no one can sit on it, he will be, so to speak, placed under the protection of the general will, without at all being able to identify himself with it. [He is] neither supreme leader, nor representative of the sovereign, but guardian of an empty place from which no one can talk because no one can occupy it. ${ }^{126}$ Loughlin himself, in his essay on 'The Constitutional Imagination' cites Claude Lefort's depiction of the 'locus of power' in modern government as 'an empty place'.127 This is a form of emptiness that remains after, in Loughlin's words, 'the transcendent figure of the sovereign is effaced'. ${ }^{128}$ If I understand him correctly, Loughlin would see his project as the elaboration of a form of public law that is able to 'fill' this modern 'vacuum'; though, crucially, without any resort to exteriority or absolutes. As he describes the challenge: 'It may indeed be empty, but the place remains'. ${ }^{129}$ But

\footnotetext{
121 Cf. Ibid., 50.

${ }^{122}$ Cf. Ibid., 180 (referring to 'pockets of order').

${ }^{123}$ For a rich, normative account of a political philosophy with such features, see again Connolly (1999).

${ }^{124}$ Cf. Rapaport (1997), 216.

125 Notably in Hermann Heller's idea of an ethical foundation to law which 'has content, though one which is not prescribed by any particular philosophy or ideology'. See David Dyzenhaus, Hermann Heller and the Legitimacy of Legality (1996) OXFORD JOURNAL OF LEGAL STUDIES 651. See also De Vries, General and Divine Economy (2005), 132.

126 Scubla (1998), cited in Dupuy (2013), 149.

127 Martin Loughlin, The Constitutional Imagination (2015) MODERN LAw REviEw 11; also in Dupuy (2013), 148

${ }^{128}$ Loughlin, ibid.

129 Ibid.
} 
would it not be more in keeping with Loughlin's own arguments to argue that it is rather maintaining these spaces as empty ground, protecting them against occupation and forever deferring their dissolution, that constitutes the task for which public law as political jurisprudence may be uniquely suited?

\section{CONCLUSION}

There are no foundations, Loughlin tells us in 'Foundations of Public Law'. It is droit politique all the way down. There is fundamental law, but there cannot be any fundamentalism. Public law's purpose is precisely to prevent, by postponing indefinitely, any kind of grounding in absolutes. It can only do this if it can safeguard its own fundamental-ness. Doing that, Loughlin argues, requires an immanent discourse of irreconcilability. ${ }^{130}$

On the first point, I have argued that given Loughlin's general outlook of favouring openness and paradox, the categorical affirmation that public law has to be entirely immanent is incongruous. If the 'radical originality of democratic society' really is 'always to question itself, 131 should this questioning not also be extended to the way the boundaries of the discourse of political right are conceived?132 And so, instead of the pursuit of an impossible radical immanence, we may do better trying to understand political jurisprudence as generative of, and supported by, a highly particular kind of exteriority: an un-occupiable, in-between space for public discourse that is simultaneously, and from different perspectives, transcendent and immanent.

On the second issue, I have claimed that the concern to safeguard irreducibility and to prevent the elimination or reconciliation of the vital contradictions of living together, may draw support from the practices of ritual. Ritualised modes of acting may be uniquely well-suited to a world where identities and boundaries are in need of both constant affirmation and transgression, so as to both allow for their existence and to guard against their absolutisation. Ritualisation is also an appropriate frame for understanding the kind of reflexivity that Loughlin places at the heart of political jurisprudence. It offers an understanding of dynamics through which men and women can be made before law what they ought to become through law. Ritual, after all, is often a key site for

\footnotetext{
${ }^{130}$ In this essay, I have taken Loughlin's objective of assuring irreconcilability through public law on its own terms. I have not discussed possible objections to that overall project, such as that the discourse of public law construes an abstract concept of a public sphere rather than any actual, genuinely open sphere itself; or the idea that speaking of public law reveals more about the speakers than about what is spoken of (cf. Asad (1993) 40; Bell (2009), 4; cf. Bourdieu (2014), 28, on the 'divinization effect' of neutrality).

131 Cf. Gauchet, Tocqueville (1994), 108.

132 Cf. Connolly (1999), 5-8, 19-46.
} 
the construction of both normality and of normativity, and for dialectical movement between the two. ${ }^{133}$

This turn towards ritual has important implications for the study and the practice of public law as political jurisprudence. For one, it sits somewhat uneasily with Loughlin's own turn towards symbolism in his more recent work on 'The Constitutional Imagination'. ${ }^{134}$ The strands of anthropological work he draws on there, notably the symbolic anthropology of Clifford Geertz, have been criticised for assuming and emphasising forms of coherence and harmony of ideas that are difficult to reconcile with Loughlin's own arguments in support of contradiction. ${ }^{135}$ Apart from Geertz's insights, then, further work on the discourse and the practice of political jurisprudence might draw on other anthropological work, such as that by Edmund Leach on the 'grammar' of ritual, or by Talal Asad cited earlier - on practice and discipline. ${ }^{136}$

Most importantly, the ritualisation perspective serves as a useful reminder that negotiating the tensions of common life requires effort. 'Ritual is endless work', it has been said, 'but it is among the most important things we humans do'.137 Much the same could be said of our efforts to maintain a genuinely open register of public reason, in the form of a prudential discourse of political right. That discourse, though, as I have argued, may have to be somewhat more like religion, and somewhat less like law, than Loughlin envisages.

\footnotetext{
133 The game analogy in David Dyzenhaus's discussion of Heller is illustrative for its closeness to ritual dynamics. See Dyzenhaus (1996), 654.

${ }^{134}$ Loughlin (2015). Note that FPL despite its explicit mentions of the importance of 'practice' in fact offers very little discussion of any such practices, apart from some mention of early coronation rituals. ${ }_{135}$ Cf. Bell (2009), 28-30; Asad (1993).

${ }_{136}$ Cf. Bell (2009), 68, 79.

137 Seligman et al. (2008), 182.
} 